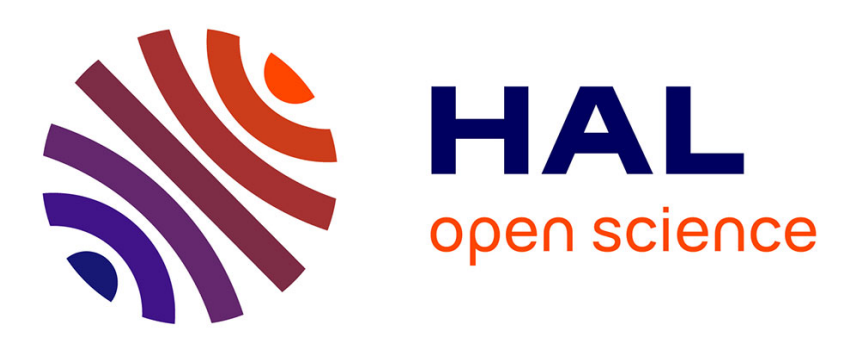

\title{
Pillared sulfonate-based metal-organic framework as negative electrode for Li-ion batteries
}

Marine Cognet, Thibaut Gutel, Romain Gautier, X. F Le Goff, Adel Mesbah, Nicolas Dacheux, Michaël Carboni, Daniel Meyer

\section{- To cite this version:}

Marine Cognet, Thibaut Gutel, Romain Gautier, X. F Le Goff, Adel Mesbah, et al.. Pillared sulfonatebased metal-organic framework as negative electrode for Li-ion batteries. Materials Letters, 2019, 236, pp.73-76. 10.1016/j.matlet.2018.10.082 . hal-01972326

\section{HAL Id: hal-01972326 \\ https://hal.science/hal-01972326}

Submitted on 19 Nov 2020

HAL is a multi-disciplinary open access archive for the deposit and dissemination of scientific research documents, whether they are published or not. The documents may come from teaching and research institutions in France or abroad, or from public or private research centers.
L'archive ouverte pluridisciplinaire HAL, est destinée au dépôt et à la diffusion de documents scientifiques de niveau recherche, publiés ou non, émanant des établissements d'enseignement et de recherche français ou étrangers, des laboratoires publics ou privés. 


\title{
Pillared Sulfonate-Based Metal-Organic Framework As Negative Electrode For Li-Ion Batteries
}

Marine Cognet, ${ }^{\mathrm{a}}$ Thibaut Gutel*, ${ }^{\mathrm{b}}$ Romain Gautier, ${ }^{\mathrm{c}}$ Xavier F. Le Goff, ${ }^{\mathrm{a}}$ Adel Mesbah, ${ }^{\mathrm{a}}$ Nicolas Dacheux, ${ }^{\mathrm{a}}$ Michaël Carboni*, ${ }^{\mathrm{a}}$ Daniel Meyer ${ }^{\mathrm{a}}$

${ }^{a}$ Institut de Chimie Séparative de Marcoule, CEA, CNRS, ENSCM, Univ Montpellier, BP 17171, 30207 Bagnols-sur-Cèze Cedex, France

${ }^{b}$ CEA, LITEN, DEHT, STB, 17 rue des Martyrs, F-38054 Grenoble cedex 9, France

${ }^{c}$ Institut des Matériaux Jean Rouxel (IMN), Université de Nantes, CNRS, 2 rue de la Houssinière, BP 32229, 44322 Nantes Cedex 3, France

\begin{abstract}
The syntheses of sulfonate-based metal-organic frameworks (MOFs) following or not a pillared strategy using a linear N-donor ligand have been successfully developed. These MOFs based on $\mathrm{Co}, \mathrm{Ni}$ or Mn present a layered structure separated by a solvent molecule of DMF or by a bridging ligand (4,4'-BiPyridine - bpy). Due to the presence of transition metals on the coordination nodes bridged by ligands (bpy), these materials have been tested as negative electrodes materials in a coin cell. It reveals that materials have capacities up to $350 \mathrm{mAh} \cdot \mathrm{g}^{-1}$ and good electrochemical stability over 50 charge/discharge cycles. This strategy may shed light on designing new MOF-based electrode materials with the use of organic ligands structured in a hybrid material.
\end{abstract}

Keywords: Metal-Organic Framework; Li-Ion Battery; Negative electrodes; Sulfonate based MOF; Pillared strategy

\section{Corresponding information:}

* michael.carboni@cea.fr / tel: (+33) 466339204 / ICSM, UMR 5257, Bât 426, BP 17171, 30207

Bagnols-sur-Cèze Cedex, France

* thibaut.gutel@ cea.fr / tel: (+33) 838782121 / LITEN, Bât C2, 38054 Grenoble Cedex, France 


\section{Introduction}

Increased attention is focused on the design of efficient and clean energy storage devices. The development of Lithium ion Batteries (LiBs), first formulated by Armand[1] and later commercialized in large scale by Sony Corporation (1991), has grown exponentially due to their high energy density and relatively low self-discharge.[2] Research in this field has continued to display some remarkable progresses in terms of capacity, energy and cost reduction.[3] The future capabilities of this technology are correlated to the development of new electrode materials (anodes and cathodes). Anodes are mainly composed of graphite or carbonaceous materials.[4] However, some important improvements have been recently made such as the Ti-based compounds[5] or the silicon nanowires materials[6] which exhibit a good safety and cycling stability for a low cost.

Metal Organic Frameworks (MOFs) have proven to be very versatile materials due to the great number of metallic clusters or organic ligands that can be used in the construction of these materials.[7] Thanks to these characteristics, they have been tested for gas storage, [8] heterogeneous catalysis,[9] metals extraction[10] or artificial photosynthesis.[11] MOFs have also been recently proposed as new electrode materials for battery[12] as positive electrode materials[13] or as anode materials[14]. Due to the possibility to control different morphologies[15] it has been possible to prepare nanoscale carbon materials that have revealed to enhance ions intercalation performance.[16] This thermal conversion, under air[17] or $\mathrm{N}_{2}$ atmosphere[18], to carbon/metal oxide materials[19] can retain the stable porous architecture of the original MOF and give some interesting properties for electrochemical application. Some other strategies as the loading of metal nanoparticles[20] or carbon nanotubes[21] with MOF have been successfully demonstrated.

Carboxylate anions ligands[22] and neutral nitrogen heterocycles[23] are often used as linkers in MOFs because they are usually commercially available or they can be obtained quite easily by organic synthesis. Other functionalities such as sulfonate or phosphonate motifs have been considerably less studied.[24] However, we have recently shown that phosphonate based MOF have a great potential as electrode material in $\mathrm{LiBs}[25]$ and leads us to use of sulfonic acid linkers. Indeed, compared to the carboxylate analogues, [26] these ligands can easily stabilize high coordination number complexes due to the three oxygen donor atoms per sulfonate group and consequently corresponding MOFs exhibit a better thermal stability when coordinated to transition-metals.[27] But the lower structural predictability related to the versatile coordination modes of sulfonate to the metal is the main issue to obtain well-defined crystalline porous materials.[28] To increase rigidity and to favor 3D-network of such materials, the use of a mixed-ligand strategy can be efficient.[29-31] By using linear N-donor ligands during the MOFs synthesis, the possibility was shown to include these ligands in a layered structure and these MOF-based electrodes lead to high capacities and good cycling stability as shown by PANI-ZIF-67CC[32] or [ $\left.\mathrm{Ni}(\mathrm{bpy})(\mathrm{tfbdc})\left(\mathrm{H}_{2} \mathrm{O}\right)_{2}\right][33]$. In the last example, the use of the 4,4'-bipyridine (bpy) as spacer could be an original way to include a solid state organic 
molecule that has already shown great interest as electroactive moieties in polyviologen for organic batteries.[34]

Inspired by these results, we propose in this study the use of a $\mathrm{Mn}(\mathrm{II}), \mathrm{Co}$ (II) and $\mathrm{Ni}$ (II) systems based on BenzeneDiSulfonic Acid (BDS) that are stabilized with bpy ligands as potential electrode materials for LiBs. The crystal structures of these materials (Mn(BDS)(DMF) and $\mathrm{M}(\mathrm{BDS})(\mathrm{bpy})(\mathrm{DMF})_{2}, \mathrm{M}=\mathrm{Ni}, \mathrm{Mn}$ or $\left.\mathrm{Co}\right)$ ) have been solved from single crystal X-ray diffraction data. Moreover, electrochemical studies in coin cell have revealed a capacity around $350 \mathrm{mAh.g}{ }^{-1}(0.1$ $3.5 \mathrm{~V} \mathrm{vs} \mathrm{Li}^{+} / \mathrm{Li}$ ) at low rate and a good stability over charge/discharge cycles.

\section{Experimental}

Synthesis and characterizations

Reagents were purchased from Sigma-Aldrich and were used as received without further purification. The ligand BDS was synthesized according to a previous reported protocol[35] and was obtained by using hydrogen peroxide in a mixture of water and methanol containing the dithioterephthalic acid. $\mathrm{M}(\mathrm{BDS})(\mathrm{DMF})$ and $\mathrm{M}(\mathrm{BDS})(\mathrm{bpy})(\mathrm{DMF})_{2}$ were obtained by mixing 1 equivalent of ligand (50 mg, $0.2 \mathrm{mmol}$ ) with 1 equivalent $(68 \mathrm{mg}$ for $\mathrm{Mn}$ and $57 \mathrm{mg}$ for Co and $\mathrm{Ni}$ salts, $0.2 \mathrm{mmol})$ of $\mathrm{Mn}\left(\mathrm{NO}_{3}\right)_{2}\left(\mathrm{H}_{2} \mathrm{O}\right)_{9}, \mathrm{Co}\left(\mathrm{NO}_{3}\right)_{2}\left(\mathrm{H}_{2} \mathrm{O}\right)_{6}$ or $\mathrm{Ni}\left(\mathrm{NO}_{3}\right)_{2}\left(\mathrm{H}_{2} \mathrm{O}\right)_{6}$ and 1 equivalent of bpy (31 $\mathrm{mg}, 0.2 \mathrm{mmol}$ ) in the case of the pillared MOF in $5 \mathrm{ml}$ of dry DMF. The reaction was then performed in a solvothermal conditions at $120{ }^{\circ} \mathrm{C}$ for 2 days in an oven. Then the mixture was centrifuged and single crystals of each materials were isolated and solved by single crystal diffraction.

\section{Single crystal diffraction}

The crystal structures of the compounds $\mathrm{M}(\mathrm{BDS})(\mathrm{bpy})(\mathrm{DMF})_{2}(\mathrm{M}=\mathrm{Ni}, \mathrm{Mn}, \mathrm{Co})$ were solved from data collected on the single-crystal X-ray Bruker-Nonius Kappa CCD diffractometer with monochromated $\operatorname{MoK} \alpha(\lambda=0.71073 \AA$ ) at 100 (2) K. The crystal to detector distance was $60 \mathrm{~mm}$. Data collection strategy and data reduction were done with the use of SUPERGUI software. While the data related to $\mathrm{Mn}(\mathrm{BDS})(\mathrm{DMF})$ were collected with a bruker APEX II diffractometer at 150 (2) K, the absorption corrections were carried out with SADABS.[30] The determination of the structure and the final refinement was carried out with the use of the SHELXL 2016 package.[31] Crystal data and data collection details for each compound are reported in Table S1.

\section{Electrochemical characterizations}

Coin cell assembly was carried out in an argon-filled MBraun glove box using metallic lithium foil as counter and reference electrode and Celgard ${ }^{\circledR} 2400$ and Viledon ${ }^{\circledR}$ (Freudenberg) as separator, the latter soaked with a $1 \mathrm{M}$ solution of $\mathrm{LiPF}_{6}$ in a 1:1 volume mixture of ethylene carbonate (EC) and dimethyl carbonate (DMC) (UBE), serving as electrolyte. Galvanostatic cycling were performed using 
a multichannel Arbin BT-2000. Composite electrodes for the electrochemical characterization were prepared by mixing $\mathrm{M}(\mathrm{BDS})(\mathrm{bpy})(\mathrm{DMF})$, Super $\mathrm{P}{ }^{\circledR}$ (SP; Imerys) and poly(vinylidene difluoride) (PVdF, SOLEF® 5130; Solvay), in N-methyl-2-pyrrolidone (NMP; Sigma-Aldrich). The overall weight ratio was 40/40/20 M(BDS)(bpy)(DMF)/SP/PVdF. The slurry were coated on copper foil, serving as current collector, and after pre-drying disk-shaped electrodes were punched, having an average active material mass loading of about $1 \mathrm{mg} \cdot \mathrm{cm}^{-2}$ for $\mathrm{M}(\mathrm{BDS})(\mathrm{bpy})(\mathrm{DMF}) / \mathrm{SP} / \mathrm{PVdF}$. The electrodes were subsequently pressed at 10 tons for $10 \mathrm{~s}$ prior all the electrodes were dried at $80{ }^{\circ} \mathrm{C}$ for $48 \mathrm{~h}$ under vacuum. Since lithium foil served as counter and reference electrode, all potential values given herein refer to the $\mathrm{Li}^{+} / \mathrm{Li}^{0}$ redox couple.

\section{Results and discussion}

\section{Structure analyses}

The crystal structures of the three isostructural compounds $\mathrm{M}(\mathrm{BDS})(\mathrm{bpy})(\mathrm{DMF})_{2}$ with $\mathrm{M}=$ $\mathrm{Mn}, \mathrm{Co}$ and $\mathrm{Ni}$ were solved in the orthorhombic system in the Pbca space group. There are four formula units per unit cell with $\mathrm{a}=10.6241$ (8) $\AA, \mathrm{b}=11.6242(16) \AA, \mathrm{c}=19.7900(20) \AA$ (Mn), $\mathrm{a}=$

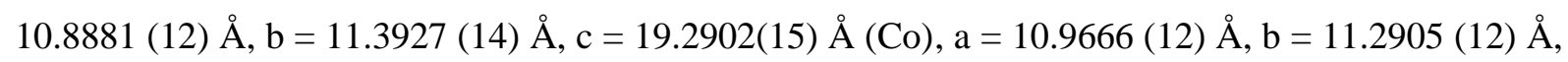
$\mathrm{c}=19.1256(8) \AA$ (Ni). Crystal data and refinement parameters are reported in Table S1. Each M has an octahedral coordination formed by four oxygen atoms, two provided by the DMF molecules and two other supplied by the sulfonate groups of the BDS molecule. The coordination sphere is completed by two nitrogen atoms coming from the bi-pyridine molecules. Figure 1-left presents a general view of the structure along the $a$ axis. The $\mathrm{MO}_{4} \mathrm{~N}_{2}$ octahedra are connected to the bi-pyridine molecules to form infinite chains along the $b$ axis. These chains are separated from each other down the $\mathrm{b}$ axis by the DMF molecules to form what could be described as organic-inorganic pseudo-layers (Figure 1-middle). The overall structure consists in BDS molecules separating these latter described pseudo-layers by the share of one oxygen atom as viewed in Figure 1-right. The interatomic distances are reported in Table S2. The M-O and M-N distances with $\mathrm{M}=\mathrm{Mn}, \mathrm{Co}$ and Ni evolve in agreement with the crystal radii reported in the Shannon tables.
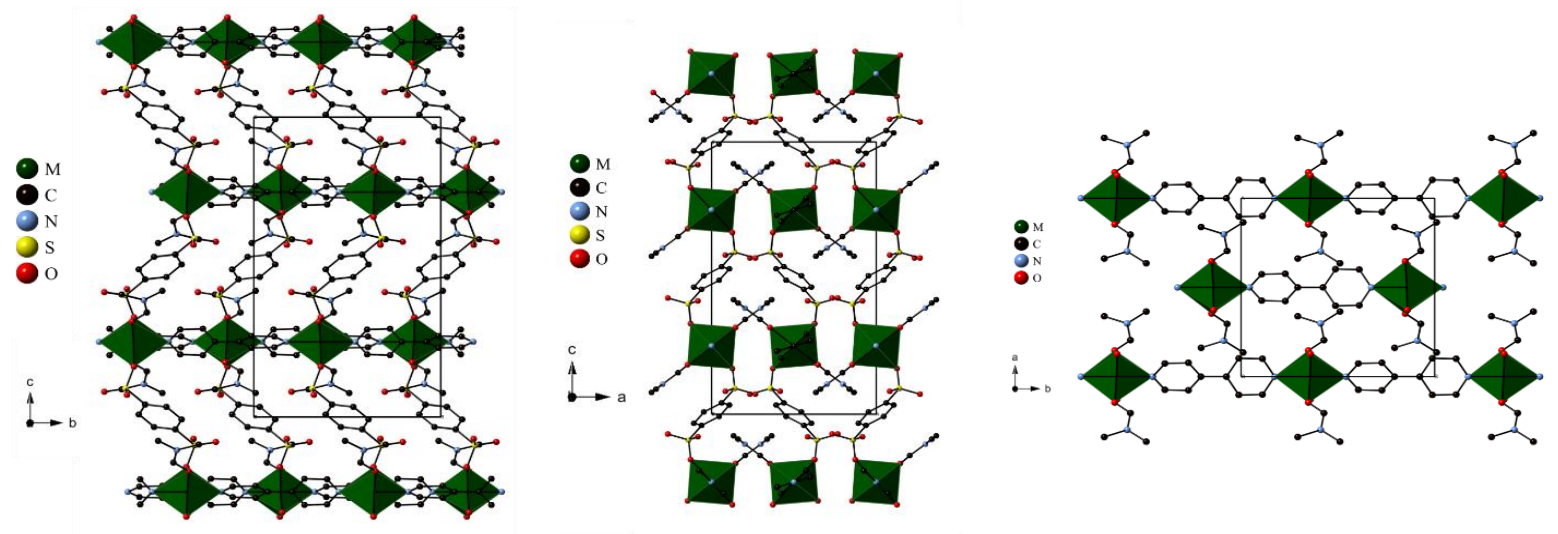
Figure 1 : left - Projection of the $\mathrm{M}(\mathrm{BDS})(\mathrm{bpy})(\mathrm{DMF})_{2}$ crystal structure down the a axis, middle crystal structure down the $\mathrm{b}$ axis, right - Arrangement of the isolated $\mathrm{MO}_{4} \mathrm{~N}_{2}$ octahedra viewed perpendicular to the [001] direction.

The materials without the bpy have also been obtained under the form of single crystal with the Manganese. $\mathrm{Mn}(\mathrm{BDS})(\mathrm{DMF})_{2}$ crystallizes in the triclinic system with the $P-1$ space group. There are two formula units per cell with $\mathrm{a}=9.858(1) \AA, \mathrm{b}=9.931(1) \AA, \mathrm{c}=10.310(1), \alpha=69.224(1)^{\circ}, \beta=$ $68.214(1)^{\circ}, \gamma=87.106(1)^{\circ}, V=872.47(15) \AA^{3}$. Crystal data and refinement parameters are reported in Table S3. In the present structure, there are two different $\mathrm{Mn}$ atoms, each one is octahedrally coordinated to six oxygen atoms. Four provided by the sulfonate group and two others belong to the DMF molecules. The difference between the two sites reside in the orientation of the DMF molecules positioned in trans configurations down the $\mathrm{b}$ axis and have different orientations. The overall structure consists of isolated $\mathrm{MnO}_{6}$ octahedra bridged by the sulfonate groups down the $\mathrm{c}$ axis and separated also by the BDS molecules down the b axis. Figure 2 represents a view of the crystal structure of the $\mathrm{Mn}(\mathrm{BDS})(\mathrm{DMF})_{2}$ compound down the $\mathrm{c}$ and $\mathrm{b}$ axis, respectively. The Mn-O distances are typical which are comprised between 2.1467(11) - 2.1831(10) $\AA$ for Mn1 and 2.1704(11) $2.1868(11) \AA$ (Table S4). It is worth noting that the crystal structure of $\mathrm{Mn}(\mathrm{BDS})(\mathrm{DMF})_{2}$ was already reported in the literature, however, from our refinement, we found that the most suitable solution consisted in doubling the volume caused in our opinion by the configuration of the DMF molecules. [36]

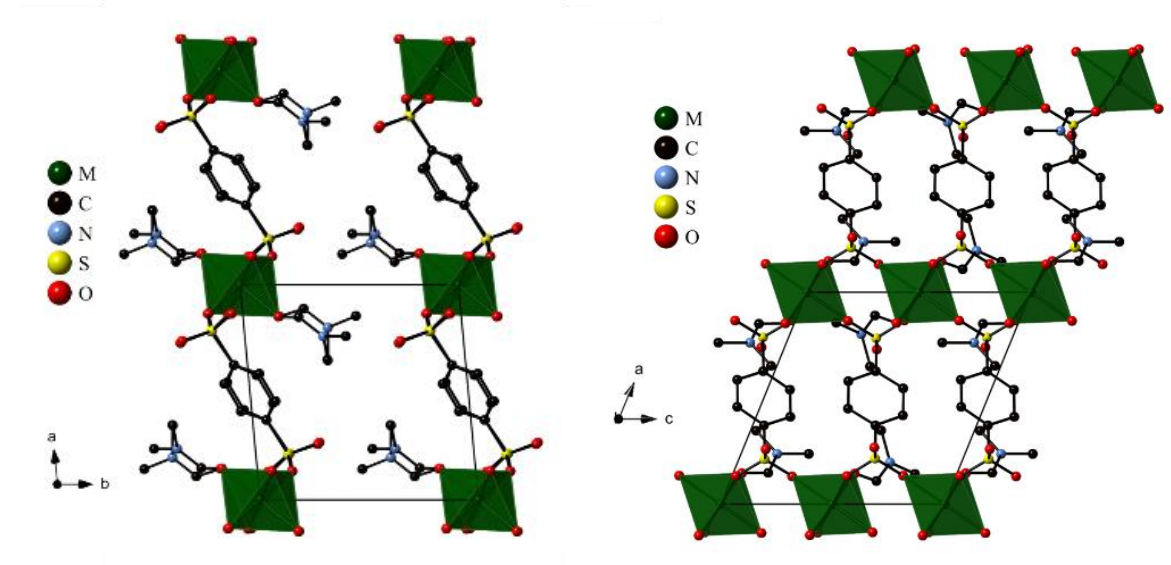

Figure 2 : (left) Projection of the $\mathrm{Mn}(\mathrm{BDS})(\mathrm{DMF})_{2}$ crystal structure down the $\mathrm{c}$ axis. (right) View of the $\mathrm{Mn}(\mathrm{BDS})(\mathrm{DMF})$ structure down the $\mathrm{b}$ axis 


\section{Electrochemical performances}

The cycling performances of M(BDS)(bpy) are shown in Figure 3 and Figure S3.
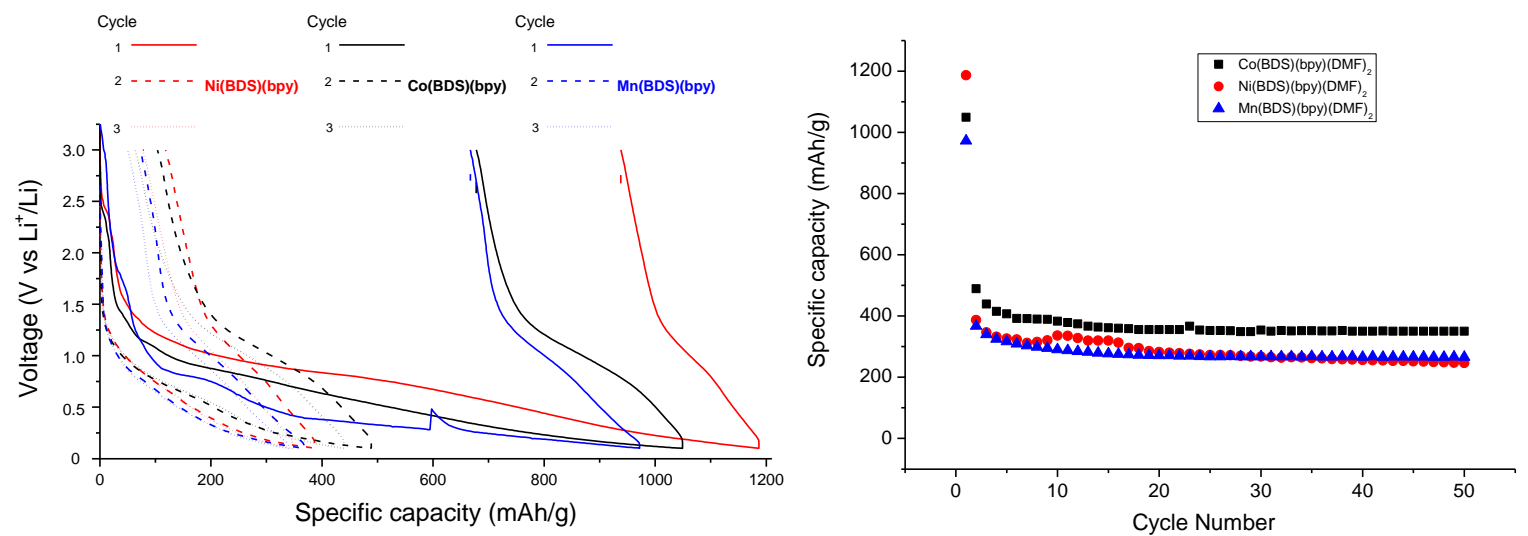

Figure 3: (left) Charge-Discharge profiles (right) and cycling performance (reduction) at $300 \mathrm{~mA} \cdot \mathrm{g}^{-1}$

The electrochemical performances of the three materials were evaluated in half coin cells. For all the materials, a first lithiation was observed with capacities up to $1200 \mathrm{mAh} . \mathrm{g}^{-1}$. Most of the capacity is observed between $1.2 \mathrm{~V}$ and $0.1 \mathrm{~V}$ with a large hysteresis. After 5 charge/discharge cycles, the specific capacity of the materials remain constant up to 50 cycles. The large irreversible capacity during the first cycles is typical of a conversion mechanism and the MOF structure is probably not maintained. However, in such material metal clusters are separated by organic ligands that lead to very small and isolated metallic particles at the end of this conversion process and avoid any particles recombination that will decrease the electrochemical performances.[37] Composite electrodes based on $\mathrm{Ni}(\mathrm{BDS})$ (bpy) and $\mathrm{Mn}$ (BDS)(bpy) have revealed the lowest capacities of the three materials with capacities of around $250 \mathrm{mAh} \cdot \mathrm{g}^{-1}$ and $260 \mathrm{mAh} \cdot \mathrm{g}^{-1}$, respectively. These capacities could be mainly attributed to the contribution of Super $\mathrm{P}{ }^{\circledR}$ carbon used to form the electrodes (Figure S1). Only the $\mathrm{Co}(\mathrm{BDS})(\mathrm{bpy})$ material has revealed a significant electro-activity with a capacity value of $350 \mathrm{mAh} \cdot \mathrm{g}^{-}$ ${ }^{1}$ (with a contribution of $2 / 5$ due to Super $P ®$ carbon in this condition). These results indicate that, even if the MOF structure is probably lost, the pre-organization of the metallic clusters is important for the overall stability during the cycling. This result is in accordance with what was observed (406 mAh.g $\left.{ }^{-1}\right)$ with the pillared $\left(\left[\mathrm{Ni}\left(4,4^{\prime}-\mathrm{bpy}\right)(\mathrm{tfbdc})\left(\mathrm{H}_{2} \mathrm{O}\right)_{2}\right]\right.$ previously reported. ${ }^{26}$ Finally, this last material presents an interesting stability after couple of charge/discharge cycles and a low operating voltage. 


\section{Conclusions}

In summary, three new pillared hybrid materials based on sulfonate ligands have been synthesized and tested as potential electrode materials. Even if the variations in ligating mode of the sulfonate can generate multiple polymorphs in such materials, it has been possible to crystallize these compounds and to solve their structures from single-crystal XRD data. The use of a bridging ligand during the MOF synthesis, i.e. the bpy, allowed to increase the distance between the MOF layers and to immobilize a molecule inside a porous network. From the different electrochemical tests, $\mathrm{Co}(\mathrm{BDS})$ (bpy) has revealed the most interesting capacity of $350 \mathrm{mAh} \cdot \mathrm{g}^{-1}$ and a good retention up to 50 cycles. These results show that the development of new electrode materials is essential to increase cell capacities and that the design of new materials can be supplied by hybrid materials.

\section{References}

[1] M.B. Armand, Intercalation Electrodes, Mater. Adv. Batter., Springer US, Boston, MA, 1980: pp. 145-161. doi:10.1007/978-1-4684-3851-2_7.

[2] J.-M. Tarascon, M. Armand, Issues and challenges facing rechargeable lithium batteries, Nature. 414 (2001) 359-367. doi:10.1038/35104644.

[3] G.E. Blomgren, The Development and Future of Lithium Ion Batteries, J. Electrochem. Soc. 164 (2017) A5019-A5025. doi:10.1149/2.0251701jes.

[4] Y. Sun, Q. Wu, G. Shi, Graphene based new energy materials, Energy Environ. Sci. 4 (2011) 1113. doi:10.1039/c0ee00683a.

[5] G.-N. Zhu, Y.-G. Wang, Y.-Y. Xia, Ti-based compounds as anode materials for Li-ion batteries, Energy Environ. Sci. 5 (2012) 6652. doi:10.1039/c2ee03410g.

[6] K. Peng, J. Jie, W. Zhang, S.-T. Lee, Silicon nanowires for rechargeable lithium-ion battery anodes, Appl. Phys. Lett. 93 (2008) 033105. doi:10.1063/1.2929373.

[7] S. Kitagawa, R. Kitaura, S. Noro, Functional Porous Coordination Polymers, Angew. Chem. Int. Ed. 43 (2004) 2334-2375. doi:10.1002/anie.200300610.

[8] J.-R. Li, R.J. Kuppler, H.-C. Zhou, Selective gas adsorption and separation in metal-organic frameworks, Chem. Soc. Rev. 38 (2009) 1477. doi:10.1039/b802426j.

[9] K. Manna, T. Zhang, M. Carboni, C.W. Abney, W. Lin, Salicylaldimine-Based Metal-Organic Framework Enabling Highly Active Olefin Hydrogenation with Iron and Cobalt Catalysts, J. Am. Chem. Soc. 136 (2014) 13182-13185. doi:10.1021/ja507947d.

[10] M. Carboni, C.W. Abney, S. Liu, W. Lin, Highly porous and stable metal-organic frameworks for uranium extraction, Chem. Sci. 4 (2013) 2396. doi:10.1039/c3sc50230a.

[11] R. Navarro Amador, M. Carboni, D. Meyer, Photosensitive titanium and zirconium Metal Organic Frameworks: Current research and future possibilities, Mater. Lett. 166 (2016) 327-338. doi:10.1016/j.matlet.2015.12.023.

[12] S.-L. Li, Q. Xu, Metal-organic frameworks as platforms for clean energy, Energy Environ. Sci. 6 (2013) 1656. doi:10.1039/c3ee40507a.

[13] E. Proietti, F. Jaouen, M. Lefevre, N. Larouche, J. Tian, J. Herranz, J.-P. Dodelet, Iron-based cathode catalyst with enhanced power density in polymer electrolyte membrane fuel cells, Nat. Commun. 2 (2011) 416. doi:10.1038/ncomms1427.

[14] F. Zheng, Y. Yang, Q. Chen, High lithium anodic performance of highly nitrogen-doped porous carbon prepared from a metal-organic framework, Nat. Commun. 5 (2014) 5261. doi:10.1038/ncomms6261.

[15] J. Tang, Y. Yamauchi, MOF morphologies in control: Carbon materials, Nat. Chem. 8 (2016) 638-639. doi:10.1038/nchem.2548. 
[16] W. Zhang, X. Jiang, Y. Zhao, A. Carné-Sánchez, V. Malgras, J. Kim, J.H. Kim, S. Wang, J. Liu, J.-S. Jiang, Y. Yamauchi, M. Hu, Hollow carbon nanobubbles: monocrystalline MOF nanobubbles and their pyrolysis, Chem. Sci. 8 (2017) 3538-3546. doi:10.1039/C6SC04903F.

[17] R.R. Salunkhe, C. Young, J. Tang, T. Takei, Y. Ide, N. Kobayashi, Y. Yamauchi, A highperformance supercapacitor cell based on ZIF-8-derived nanoporous carbon using an organic electrolyte, Chem. Commun. 52 (2016) 4764-4767. doi:10.1039/C6CC00413J.

[18] Y. Song, Y. Chen, J. Wu, Y. Fu, R. Zhou, S. Chen, L. Wang, Hollow metal organic frameworksderived porous $\mathrm{ZnO} / \mathrm{C}$ nanocages as anode materials for lithium-ion batteries, J. Alloys Compd. 694 (2017) 1246-1253. doi:10.1016/j.jallcom.2016.10.110.

[19] W. Chaikittisilp, N.L. Torad, C. Li, M. Imura, N. Suzuki, S. Ishihara, K. Ariga, Y. Yamauchi, Synthesis of Nanoporous Carbon-Cobalt-Oxide Hybrid Electrocatalysts by Thermal Conversion of Metal-Organic Frameworks, Chem. - Eur. J. 20 (2014) 4217-4221. doi:10.1002/chem.201304404.

[20] Y. Fu, Y. Li, R. Zhou, Y. Zhang, S. Chen, Y. Song, L. Wang, Co3O4 nanoparticles@MOF-5derived porous carbon composites as anode materials with superior lithium storage performance, J. Alloys Compd. 749 (2018) 645-651. doi:10.1016/j.jallcom.2018.03.338.

[21] J. Wu, Y. Song, R. Zhou, S. Chen, L. Zuo, H. Hou, L. Wang, Zn-Fe-ZIF-derived porous ZnFe 2 $\mathrm{O}_{4} / \mathrm{C} @ \mathrm{NCNT}$ nanocomposites as anodes for lithium-ion batteries, J. Mater. Chem. A. 3 (2015) 7793-7798. doi:10.1039/C5TA00805K.

[22] M. Eddaoudi, D.B. Moler, H. Li, B. Chen, T.M. Reineke, M. O'Keeffe, O.M. Yaghi, Modular Chemistry: Secondary Building Units as a Basis for the Design of Highly Porous and Robust Metal-Organic Carboxylate Frameworks, Acc. Chem. Res. 34 (2001) 319-330. doi:10.1021/ar000034b.

[23] K.S. Park, Z. Ni, A.P. Cote, J.Y. Choi, R. Huang, F.J. Uribe-Romo, H.K. Chae, M. O'Keeffe, O.M. Yaghi, Exceptional chemical and thermal stability of zeolitic imidazolate frameworks, Proc. Natl. Acad. Sci. 103 (2006) 10186-10191. doi:10.1073/pnas.0602439103.

[24] G.K.H. Shimizu, R. Vaidhyanathan, J.M. Taylor, Phosphonate and sulfonate metal organic frameworks, Chem. Soc. Rev. 38 (2009) 1430. doi:10.1039/b802423p.

[25] M. Cognet, T. Gutel, D. Peralta, J. Maynadié, M. Carboni, D. Meyer, Iron(II)-Benzene Phosphonate Coordination Polymers as an Efficient Active Material for Negative Electrode of Lithium-Ion Batteries, J. Electrochem. Soc. $164 \quad$ (2017) A2552-A2554. doi:10.1149/2.1231712jes.

[26] G.P. Panasyuk, L.A. Azarova, G.P. Budova, A.P. Savost'yanov, Copper terephthalate and its thermal decomposition products, Inorg. Mater. 43 (2007) 951-955. doi:10.1134/S0020168507090075.

[27] A. Mietrach, T.W.T. Muesmann, J. Christoffers, M.S. Wickleder, Sulfonic Acid Analogs of Terephthalic and Trimesic Acid as Linkers in Metal-Organic Frameworks - Synthesis of Thermally Robust MOFs, Eur. J. Inorg. Chem. 2009 (2009) 5328-5334. doi:10.1002/ejic.200900914.

[28] A.P. Cote, G.K.H. Shimizu, The supramolecular chemistry of the sulfonate group in extended solids, Coord. Chem. Rev. 245 (2003) 49-64. doi:10.1016/S0010-8545(03)00033-X.

[29] Z.-X. Lian, J. Cai, C.-H. Chen, A series of metal-organic frameworks constructed with arenesulfonates and 4,4'-bipy ligands, Polyhedron. $26 \quad$ (2007) 2647-2654. doi:10.1016/j.poly.2007.01.002.

[30] G. Zhang, G. Wei, Z. Liu, S.R.J. Oliver, H. Fei, A Robust Sulfonate-Based Metal-Organic Framework with Permanent Porosity for Efficient $\mathrm{CO}_{2}$ Capture and Conversion, Chem. Mater. 28 (2016) 6276-6281. doi:10.1021/acs.chemmater.6b02511.

[31] D.K. Maity, K. Otake, S. Ghosh, H. Kitagawa, D. Ghoshal, Sulfonic Group Functionalized Mixed Ligand Coordination Polymers: Synthesis, Characterization, Water Sorption, and Proton Conduction Studies, Inorg. Chem. 56 (2017) 1581-1590. doi:10.1021/acs.inorgchem.6b02674.

[32] L. Wang, X. Feng, L. Ren, Q. Piao, J. Zhong, Y. Wang, H. Li, Y. Chen, B. Wang, Flexible Solid-State Supercapacitor Based on a Metal-Organic Framework Interwoven by Electrochemically-Deposited PANI, J. Am. Chem. Soc. 137 (2015) 4920-4923. doi:10.1021/jacs.5b01613. 
[33] C. Shi, X. Wang, Y. Gao, H. Rong, Y. Song, H.-J. Liu, Q. Liu, Nickel metal-organic framework nanoparticles as electrode materials for Li-ion batteries and supercapacitors, J. Solid State Electrochem. 21 (2017) 2415-2423. doi:10.1007/s10008-017-3591-6.

[34] L. Striepe, T. Baumgartner, Viologens and Their Application as Functional Materials, Chem. Eur. J. 23 (2017) 16924-16940. doi:10.1002/chem.201703348.

[35] A. Mietrach, T.W.T. Muesmann, J. Christoffers, M.S. Wickleder, Sulfonic Acid Analogs of Terephthalic and Trimesic Acid as Linkers in Metal-Organic Frameworks: Synthesis of Thermally Robust MOFs, Eur. J. Inorg. Chem. 2009 (2009) 5328-5334. doi:10.1002/ejic.200900914.

[36] C. Zitzer, T.W.T. Muesmann, J. Christoffers, C. Schwickert, R. Pöttgen, M.S. Wickleder, 1,2,4,5-Benzenetetrasulfonic acid and 1,4-benzenedisulfonic acid as sulfo analogues of pyromellitic and terephthalic acids for building coordination polymers of manganese, CrystEngComm. 16 (2014) 11064-11077. doi:10.1039/C4CE01618A.

[37] H.H. Lee, J.B. Lee, Y. Park, K.H. Park, M.S. Okyay, D.-S. Shin, S. Kim, J. Park, N. Park, B.-K. An, Y.S. Jung, H.-W. Lee, K.T. Lee, S.Y. Hong, Coordination Polymers for High-Capacity LiIon Batteries: Metal-Dependent Solid-State Reversibility, ACS Appl. Mater. Interfaces. 10 (2018) 22110-22118. doi:10.1021/acsami.8b04678. 